W. Koesters and others of world-wide repute, as well as the British and American representatives. It is pleasant to be able to record that the proceedings were without constraint and of the friendliest, so that it might have been a gathering of scientific friends at a German university before the First World War.

Many of those present for the ceremony stayed at Gottingen for a further day or two, and the occasion was one of much discussion of the newly founded Max-Planck-Gesellschaft, under which title the old Kaiser-Wilhelm-Gesellschaft has been reconstituted. This comprises thirty-four research institutes in the British and American Zones, of which six are at Göttingen. The president is Otto Hahn, the discoverer of uranium fission, and other Göttingen notabilities prominently associated with the Society are von Laue, Heisenberg and Windaus. The head of the management (Geschäftsführender Vorstand) is Dr. Ernst Telschow, who was a prominent figure at the discussions that took place. The Max Planck Institute for Physics under Werner Heisenberg is accommodated in a fine building of the AVA, and is largely concerned with cosmic rays, both from the theoretical and experimental points of view, with the particular aim of elucidating the reciprocal transformations of waves and particles. Superconductivity and astrophysics will also be prominent subjects of study. Theoretical work is in full swing, but so far it has not proved possible to erect the refrigerating apparatus necessary for experimental work on superconductivity. Much apparatus for cosmic ray research is already working.

Active work on the more theoretical aspects of aerodynamics and hydrodynamics is proceeding in the Max-Planck.Institut für Strömungsforschung under Walter Tollmien, who has succeeded Prandtl, still a prominent figure, though retired on account of age. In the same Institute much work is being carried out on friction. There are also Institutes for Brain Physiology, Medicine, Scientific Instruments and Physical Chemistry.

There are many difficulties in building up scientific work at Göttingen, but how they compare with those in Britain would be a matter for detailed study, possibly not without controversy. However, what is incontrovertible is that the spirit is excellent and that there is every hope that Göttingen will soon be once more an active source of scientific results of the highest importance. Much credit in this connexion is due to Dr. B. K. Blount, of the Control Commission, who has carried out a difficult task with equal tact and efficiency.

$$
\text { E. N. da C. Andrade }
$$

\section{LYON PLAYFAIR AND TECHNICAL EDUCATION IN BRITAIN}

\section{By W. H. G. ARMYTAGE \\ University of Sheffield}

$\mathrm{T}$ HIS year marks the fiftieth anniversary of the death on May 29 of Lyon Playfair, chemist and statesman. In both roles he made a name that lives today, for as a chemist he played a large part in the discovery of the nitroprussides and (with Bunsen) made a valuable report on the gases evolved in iron furnaces; while as a statesman he urged, by every means in his power, the adoption of the new scientific knowledge and techniques. In both spheres he fulfilled the role of one of the chief architects of the system of technical education in Great Britain as it exists to-day.

The whole logic of Playfair's career lay in this. He was trained as a medical man; but his subsequent studies under, and friendship with, Liebig made him alive to the necessity of applying organic chemistry to other fields, as Liebig had applied it to agriculture. By the time he was twenty-four he had established such a reputation for himself that, when he wished to take up a professorship in Toronto, the Prime Minister personally requested him to stay in England. For his practical bent had been appreciated, and soon afterwards he was a professor at the School of Mines in Jermyn Street, exploring the possibilities of coal for steam navigation, and the causes of potato disease in Ireland. In view of all this activity, it was not surprising that he was elected to fellowship of the Royal Society when he was thirty.

The main event of Playfair's life was the Great Exhibition of 1851. The idea was Prince Albert's. Its projection was in the hands of a Royal Commission, and at times the Royal Commission clashed with Prince Albert's executive committee. Playfair was appointed as a liaison officer between the two bodies, and his grasp of the situation was responsible for the organisation of the juries being delegated to him. This work made his name. He was made a C.B. and given a place in the household of the Prince Consort. Henceforth, as the later exhibitions of 1862 and 1875 show, he was to be closely identified with this kind of work.

The Prince Consort was anxious to devote the profits of the Great Exhibition $(£ 186,436)$ to the practical application of science and art to productive industry. This scheme was vigorously supported by Playfair; so vigorously, in fact, that his vehemence on the subject caused him to be suspected of secularism. Eventually, when the report of the commissioners was published, it was decided to supplement the profits by a parliamentary grant of $£ 150,000$, and to purchase the three estates of Gore House (21 acres), Villiers (48 acres) and Harrington (17 acres). On this land, from now on called South Kensington, the Prince Consort intended to concentrate all the existing institutions already in existence. So ambitious a project, however, was not immediately practicable, and a start was made with the foundation of the Royal College of Science.

The real result of the Great Exhibition from our point of view was the establishment of a government department to encourage technical education, and it was, significantly enough, originally constituted under the Board of Trade as a dual department. Playfair was appointed as first secretary of the Science Department in 1853, and later, when the Art Department merged with the Science Department and came under the Committee of the Privy Council, he was made responsible for the united body. He now held a position vis-d-vis technical instruction as important as James Kay-Shuttleworth had held in the world of elementary education. But unfor. tunately for technical education, the Crimean War proved a serious handicap to his efforts. For not only were extensive grants to the new department impossible, but also Playfair's time was monopolized by the Government in experiment. The importance of his position was not lost on him, and he wrote a telling pamphlet called "Industrial Education on the Continent", demanding an official inquiry on the 
subject. It was the overture to a theme that he was never too tired to expound, and from now on the correspondence column of The Times was a convenient platform on which he could exhibit his ideas.

When Playfair was forty years of age he was elected to the professorship of chemistry at Edinburgh. A fortunate marriage the year before made it unnecessary for him to work for his living as a Civil Servant, and it enabled him to build up a teaching laboratory. To this latter purpose he devoted all his professorial income during his first year, and a large part of it during succeeding years. So it is not surprising that when the 1867 Reform Bill allotted two seats to the four Scottish Universities, Playfair was returned as first member by a majority of 250.

His political career, though marked by the tenure of office, is remarkable rather for his effective work as a committee member than for any startling reforms in administration or legislation. Yet it must be remembered that the hinterland of all legislation in the nineteenth century was the select committee's report, and in this connexion his work is of the greatest significance. For as chairman of the commission of inquiry into the selection and staffing of the Civil Service, he was responsible for the report that bears his name. This report made possible the smooth running of the administrative machine that was being created by the increasing demands of the State. He was Postmaster-General at the end of Gladstone's first ministry, Deputy Speaker in the first three years of the second, and Vice-President of the Committee of Council (virtual Minister of Education) in the third. When Gladstone came to power for the last time, in 1892, Playfair was ennobled as Baron Playfair. Throughout he was a prominent speaker on all university questions, and did not hesitate to attack Gladstone for his attempt in 1873 to establish the Irish universities on the model of the University of London.

But throughout the years of opposition, Playfair returned to the subject which lay nearest his heart - the continuance of the work initiated by the Great Exhibition. The commission which had been set up to manage the South Kensington estates had landed itself in financial straits by overbuilding. When Playfair took over the honorary secretaryship in 1883 , it was $£ 180,000$ in debt, with an annual deficit of $£ 2,000$. He remained in office for six years (until his seventieth birthday), and reduced the debt by $£ 174,000$, and had converted the annual deficit to a surplus. In addition, he had elaborated a scheme whereby the surplus funds could be utilized in research scholarships at home and abroad.

As Lord Playfair, he had every inducement to play the part of Nestor and leave the work to younger men ; but emancipation from political office seemed to intensify his efforts to promote technical education. His last plea, a letter in The Times of February 8, 1897, advocated the completion of the art and science museums at South Kensington, then set in a squalor that did not suit the splendid collections which they already housed. His letter initiated a response from many who were anxious to commemorate Queen Victoria's diamond jubilee. It was a fitting last act of his life. A year after his death, the Queen laid the foundation stone of the Victoria and Albert Museum, and, as has been well said, so long as South Kensington exists, Lyon Playfair will not lack a memorial.

\section{OBITUARIES}

\section{Prof. F. O. Bower, F.R.S.}

Frederick OrPen Bower was born at Ripon in Yorkshire on November 4, 1855. He came of a long-established Yorkshire family. His father, Abraham Bower, J.P., was a man of leisure and his mother, Cornelia, was daughter of Rear-Admiral Henry Gage Morris. They had a family of three girls and two boys.

He frequently referred in later life to early happy days spent botanizing and bird nesting in the fields around Ripon, and there, no doubt, his interest in natural history was initiated. In 1868 he went to Repton School, and we find that his first published work, a poem in the heroic style on "Livingstone", won a prize. He was impatient at the lack of opportunity to study science, and on that account does not seem to have fully enjoyed his time at school. In 1874 he went to Trinity College, Cambridge. In Cambridge he found the official teaching in botany, to use his own words, "moribund in summer and actually dead in winter". When the English trans. lation of Sachs' text-book of botany appeared in 1875 and he met S. H. Vines, the horizon brightened. $\mathrm{He}$ graduated with first-class honours in botany. $\mathrm{He}$ witnessed the conferment of an honorary degree on Charles Darwin. For a short time he lectured for a committee concerned with higher education of women, and he coached and worked in the laboratory with Vines. In 1877 he went with Vines to Würzburg, where he studied under Sachs, who evidently made a great impression on him.

In 1879, working under de Bary at Strassburg, he met a number of the most active continental botanists. Bower, Vines, Scott and other British botanists came back from Germany inspired by the instruction they received there in new aspects of botany and new technical advances in research. They introduced new vitality to the British schools, which had been concentrating on pure systematics and had been out of touch with the progress that was being made in other branches of botany on the Continent. Bower maintained in later years a close contact with his continental friends and was corresponding member of the Royal Academy of Turin and of the Botanical Society of America and a member of the Royal Society of Belgium, the Academy of Science of Munich and of the Royal Danish Society. His first published research was produced in Strassburg, on growth of the cell wall in Draccena and on the development of the conceptacle of Fucus.

In 1880 he was assistant to Daniel Oliver at University College, London, and later became a lecturer under T. H. Huxley. While he held these posts he spent much of his spare time working at the Jodrell Laboratory at the Royal Botanic Gardens, Kew. Here was developed his interest in the vascular cryptogams, which were to occupy so much of his attention in later years. In 1885 he was appointed to the regius chair in Glasgow, which he occupied until 1925. When he went to Glasgow he found that his official teaching was restricted to the medical botany class in the summer term, and it was not until about 1893 that botany became a subject for the degree of B.Sc., and was taught throughout the session. He had, therefore, ample time for research, and between 1885 and 1886 spent about six months in Ceylon. $\mathrm{He}$ also continued to work during the winter months at Kew. He was an inspiring lecturer, 